\title{
Homens da Fronteira: índios, capitães e sertanismo na Ilhéus setecentista
}

Men of the frontier: indians, masters and sertanismo in 18th century Ilhéus

Rafael dos Santos Barros*

barrosrafaeldossantos@gmail.com

Resumo: O presente artigo discorre sobre uma etapa das expedições que percorreram a Capitania dos Ilhéus durante a primeira metade do século XVIII. Formada por inúmeros agentes coloniais, estas jornadas devassaram o interior da região em busca de índios para serem escravizados, metais preciosos e quilombos para serem destruídos. As entradas também visavam evitar que os contra-ataques indígenas prejudicassem a produção de viveres da donataria para Salvador. Para isso, a Coroa investirá de poder as autoridades locais, premiando com cargos e mercês aqueles que se empenhavam em tais empreendimentos. Neste processo de exploração, os indígenas não foram vítimas pacíficas, pois souberam incorporar os códigos de funcionamento do sistema colonial, agindo, muitas vezes, em função dos seus interesses, ora combatendo grupos inimigos, ora denunciando a sua localização.

Palavras-chave: sertanismo, Capitania dos Ilhéus, índios

Abstract: This article discusses a stage of expeditions which swept the Captaincy of Ilheus during the first half of the eighteenth century. Formed by numerous colonial agents, these journeys devastated the interior of the region in search of Indians to be enslaved, precious metals and quilombos to be destroyed. For this, the Crown invest power to local authorities, awarding positions and favors those who engaged in such ventures. In this process of exploration, the Indians were not peaceful victims as they learned how to incorporate the operation codes of the colonial system according to their purposes, either fighting enemy groups or denouncing its location

Keywords: sertanismo, Captaincy of Ilhéus, indians

*Mestrado em História do Brasil pela Universidade Federal da Bahia (UFBA). 


\section{Introdução}

A Capitania dos Ilhéus cumpriu dentro do sistema colonial a função de abastecedora de alimento. Já em 1674, foi proibido o estabelecimento de engenhos, ou canaviais, bem como a criação de gados nessa região, pois essa donataria era responsável pela manutenção do mercado interno de Salvador e seu Recôncavo. Desta forma, durante a primeira metade do século XVII, foram organizadas várias jornadas ao sertão da Capitania dos Ilhéus para combater os índios que estavam atacando as vilas da região, principalmente as de Camamú, Cairú e Povoação do Rio de Contas. Caso esses índios não fossem combatidos, segundo os moradores, provocariam uma crise no abastecimento dessas localidades e das praças comerciais de Salvador.

De modo geral, a historiografia balizou semelhanças e diferenças entre entradas e bandeiras. Basílio de Magalhaes foi um dos precursores a estabelecer uma divisão esquemática que distinguia essas expedições, subdividindo-as de acordo em dois tipos: a primeira caracterizou-se por ser um pequeno ciclo de expansão oficial, realizada entre 1504 e 1696 dentro da Linha de Tordesilhas. Já no segundo caso, dizia respeito a uma grande expansão territorial, subdivididano ciclo da caça ao índio e no ciclo do ouro.

Outra definição possível foi proposta por Pedro Puntoni. Conforme o autor, bandeira eram "expedições de caráter misto, meio civil, meio militar, que, além do cativeiro dos índios, se interessavam nas descobertas de metais preciosos" (PUNTONI, 2002, p. 199). Já as entradas seriam aquelas expedições organizadas pelo Estado, por conta própria, objetivando a caça do gentio. Figurou em Ilhéus o segundo caso, onde foram organizadas pela Coroa inúmeras expedições com o objetivo de capturar o "gentio de corso".
Além de abastecedora, a supracitada capitania situava-se em um ponto estratégico que a ligava às $\mathrm{Mi}$ nas do Rio de Contas. Assim combater os grupos indígenas tornou-se de suma importância, haja vista os altos valores obtidos na prospecção de ouro, caso esse fosse encontrado nas proximidades da capitania dos Ilhéus. Lidar com povos ainda em fase inicial de contato, a exemplo de alguns ramos dos Aimoré-Gueren, tornou-se uma das grandes dificuldades que enfrentavam as autoridades coloniais do período, conforme nos informa um documento da época:

[...] o gentio Grens que há muitos anos infesta com repetidos assaltos as povoações do Cairú feitorias da Madeirasjequiriça e estradas que vai para as Minas do Rio de Contas, donde tem feito muitas mortes e outras hostilidades (APB. Ordens Régias 1729 seção de arquivo colonial provincial).

Era esse o desafio que enfrentavam as autoridades da capitania dos Ilhéus nas primeiras décadas do século XVIII. Mergulhados nesse ambiente de expansão das fronteiras estavam os inúmeros povos indígenas que habitavam essa área, os quais foram homogeneizados e combatidos, destinando-lhes inúmeras jornadas punitivas como veremos nas linhas que seguem.

Ser índio em uma zona de fronteira: Entradas contra os bárbaros povos

As ações colonizadoras passam por processos, que embora distintos, têm o objetivo de impor a dominação de um grupo sobre o outro. Dentre as fases do processo de colonização, podemos destacar quatro etapas: conquista, dominação, colonização e, por fim, a civilização. Como noticia Paraíso (PARAÍSO, 1998, p. 29), a integração dos indígenas à sociedade colonial não ocorre de forma linear e definitiva, uma vez que existem etapas que não são cumpridas no conjunto da dominação. Diante dessas ponderações da autora e, baseando-se na história dos índios da Capitania dos 
Ilhéus, podemos concluir que, em alguns contextos históricos, a colonização foi tão nociva aos indígenas que os opressores se limitaram à ocupação dos antigos territórios, uma vez que os povos que ali viviam foram totalmente aniquilados ou removidos para aldeamentos. Nessas localidades os indígenas adquiriram novos hábitos a fim de atender ao projeto do colonizador.

Devemos ressaltar, porém, que o processo de dominação não se limita às ações armadas e aos aldeamentos, uma vez que a partir de distintas relações econômicas, políticas e sociais também pôde se desencadear a dominação de um grupo sobre o outro. Como exemplo dessa assertiva precedente, permite-nos destacar as relações de alianças político-militares e de vinculações comerciais entre colonos e indígenas, as quais na sua grande maioria são relações baseadas em interesses recíprocos, mas que, em alguns casos, podem ser nocivas a algumas partes dos grupos envolvidos.

Expandir os limites territoriais da Capitania dos Ilhéus exigiu das autoridades coloniais grandes investimentos e um aparato militar de grande monta para poderem realizar essa expansão. Ao analisar os homens envolvidos no processo de expansão das fronteiras há que levarmos em conta as motivações que impeliram esses grupos a buscarem novas alternativas sociais. As motivações estavam relacionadas desde razões religiosas até ambições puramente econômicas.

A conquista dos territórios do interior da Capitania dos Ilhéus relaciona-se a uma grande variedade de elementos que faziam parte do empreendimento colonial. Entre eles vale destacar a manutenção de Salvador como centro exportador, levando o Estado a organizar inúmeras jornadas, pois, durante a segundo metade do século XVII uma onda de ataques indígena assolaram as Vilas de Baixo, fato informado por uma carta enviada pelo Conde de Castelo Melhor ao sargento-mor Antônio de Couros Carneiros, a qual descrevia os sucessos obtidos por índios que atacaram moradores da capitania de Ilhéus, impedindo a produção e envio de farinha para Salvador. Não contornada a situação dos ataques dos índios AimorélGueren as vilas da capitania, o dito conde ordena ao padre superior da Aldeia do Camamú que,

\section{[...] tenha previnido 40 indio os melhores ( que são os menos que se podiam tirar dessa Aldeia) e os arme de toda a frecharia que poderem trazer e estejam proposto, para todas as horas que por aviso se embarcarem, e virem para esta praça donde se ajunta toda a gente que há de ir a esta empresa (DHBN, v. 3, p. 163).}

Para que esses índios fossem coordenados com maior efeciência, o seu administrador, o padre Antônio de Sá nomeou um capitão dos índios, o indígena Ignácio Taveira "para tomar armas, quando se oferece ocasião de inimigos, para que como tal o seja, use, e exerça, na forma que o fazem os mais Capitães dos índios das Aldeias deste Estado". Ignácio deveria exercer alguma espécie de liderança entre os 40 índios que o acompanharam e, certamente, tinha a confiança do seu administrador. Caso a jornada fosse bem sucedida, prometia ao padre "grande parte do bom sucesso". Para essa jornada, a Câmara de Salvador tirou um grandioso donativo para

\footnotetext{
[...] os resgates e por todos os que vierem se hão de repartir de modo, que tenham que levar para suas Aldeias e de que se dar por contentes de haverem vindo fazer este serviço a Sua Magestade e V.P. o não fará pequeno a Deus (DHBN, v. 3, p. 163).
}

Curiosamente em outra carta do mesmo período destinada ao sargento-mor Gaspar de Brum, o Conde de Castelo Melhor o aconselha a falar com os principais das Aldeias dos Aimoré-Gueren,

[...] que me dizem trazem guerra com estes Tapuias e prometendo-lhes o resgate que lhe parecer me traga a esta 
cidade a notícia do animo com que estão, e certeza do número que poderá ir nesta Jornada, que como há de ser em Agosto já convém adiantara-se suas prevenções (DHBN, v. 3, p. 165).

Vale também salientar que a condição de inimigos ou aliados dos portugueses não eram categorias excludentes, podendo variar num mesmo contexto histórico, uma vez que determinados grupos indígenas eram aliados de alguns colonos e hostis a outros. Pois em um mesmo contexto, um ramo dos Gueren era combatido e, ao mesmo tempo, são chamados para combater ao lado dos colonizadores. Conforme Chamboleiron, Melo e Bombardi "os grupos indígenas não mantinham apenas um tipo de tratamento em relação a todos os portugueses, mas variadas relações com diversos grupos" (2005).

Apesar dessa efetiva intervenção da Coroa portuguesa, os índios continuaram as ações ofensivas contras as Vilas de Baixo, contribuindo para a grande falta de mantimentos, segundo as autoridades da época:

\section{[...] que se acha fortaleza do Morro de} São Paulo, resultada da omissão que houve em se recardarem as farinhas que as vilas lhe estão devendo, que logo se lhe acuda com toda a que é justo haver nela assim de sobresselente para qualquer ocasião do Inimigo (DHBN, v. 41, p. 41).

Justificativas como a falta de alimentos em Salvador, e o não cumprimento das cotas do Conchavo das Farinhas foram alguns dos argumentos utilizados com muita eficiência pelas autoridades locais para atrasarem o cumprimento do Conchavo, bem como para obterem cada vez mais apoio do Estado na busca por escravos indígenas e garantirem as expansões para os sertões. Fatores climáticos, a exemplo das grandes estiagens, sonegação, dificuldades de escoamento bem como a mortalidade de escravos contribuíram muito para o agravamento da falta de alimentos, porém atribuir os problemas aos índios era bem mais vantajoso. Por conta dessas justificativas, foi armada uma grande entrada ao sertão da Capitania dos Ilhéus, tendo Antônio de Couros Carneiros como um de seus líderes, o qual levava como uma de suas principais determinações punir o atrevimento do Gentio Aimoré, usando para isso "todo calor para castigar sua insolência". A entrada iniciaria do rio das Contas e percorreria toda aquela região até Maraú para

\section{[...] dali se vir destruído todas as Aldeias de que se tem suspeita que descem; $E$ porque sendo tanto para se ter em cuida- do os [ilegivel] se não pode tirar infanta- ria alguma dessa praça, para semelhante empresa (DHBN, v. 41, p. 41).}

A fim de garantir ajuda das vilas de Cairú, Camamú e Boipeba, o Conde de Castelo Melhor fixou nessas três vilas, e também na vila de São Jorge dos Ilhéus, uma petição a fim de garantir voluntários para se reunir a expedição. Um fato curioso dessa jornada foi a presença de mercenários holandeses que, caso se reunissem aos demais, "partilhariam todos o prêmio da presa, que espero seja grande; e com a esperança do sossego em que ficaram essas vilas, a quem folgarei conservar sem o menor receio". ${ }^{\text {A }}$ presença desses "mercenários holandeses" bem como colonos de outras capitanias brasileiras, principalmente de São Paulo, estava condicionada ao partilhamento do espólio, o qual poderia ser índios escravizados, cartas de sesmarias ou títulos nobiliárquicos como gratificação pelos serviços prestados à Coroa.

Mediante formação dessa grande jornada, as vilas ficariam sem proteção contra o ataque de indígenas e ou estrangeiros, haja vista a quantidade de ho-

\footnotetext{
${ }^{1}$ BN. Carta para o Governador da Capitania dos Ilhéus Antônio de Couros Carneiros sobre a jornada do Sertão. Documentos Históricos da Biblioteca Nacional, Vol. 41, p. 41.
} 
mens e armas que haviam se deslocado para o interior da capitania. Por conta disso, o conde enviou o capitão Francisco da Rocha com sua companhia

[...] "para assistir na terra firme a ordem de Vossa Majestade; assim os moradores se haverão restituido a suas casas, a continuar o lavor das farinhas, e roças o que hei por muito encomendado a Vossa Majestade; para que se não falte com a planta (DHBN, v. 41, p. 41).

O enfrentamento entre colonos e índios no interior da capitania provocou grandes problemas aos últimos, uma vez que tiveram que enfrentar novas formas de guerrear, o uso das armas de fogo e a inexorável ambição do mercado por escravos. Esses três elementos não devem ser analisados apenas pelo aspecto das catástrofes físicas, mas também pelo terror que geravam entre os índios. Outros danos sofridos pelos índios provocados pelas guerras de conquista empreendidas pelos portugueses diziam respeito aos traumas psicológicos. Pode-se inferir, segundo as pesquisas de Paraíso, que predominava entre os grupos vencidos um forte sentimento de perplexidade. Esses traumas relacionavam-se a imposição de relações hierarquizadas, fazendo com que os índios muitas vezes ficassem sujeitos a repetidos massacres, deslocamentos forçados, escravização e perda das terras, "sinais referentes à ruína do mundo que conheciam e dominavam" (PARAÍSO, 1998, p. 31).

No início do século XVIII, as minas do rio de Contas também despertaram a atenção de Portugal, organizando de forma mais efetiva inúmeras expedições ao interior da capitania, a fim de solucionar a rebeldia dos índios Gueren que andavam "inquietando" a donataria. Nesse contexto, ao invés de contratar homens de armas da própria capitania, a Coroa buscou um experiente capitão de entradas punitivas aos índios, o paulista Antônio Veloso da Silva.

\section{A busca incansável: Metais e pedras preciosas}

Diante dessa situação observada nas linhas antecedentes, nota-se que a tônica assumida pelo Estado de Portugal para tratar com os índios gentios de Ilhéus foi quase sempre a violência. Essa assume inúmeros significados ao longo do processo colonizador, variando de significados para o violentado e o violentador conforme o tempo e o espaço. O "perigo constante" que representavam os índios para os moradores do norte dos Ilhéus tornou-se uma dos principais motivos para que os colonos os desqualificassem, criando categorias jurídicas para cada índio com que entravam em contato. Destarte, como nos pondera Ribeiro:

\section{Quando se reporta à análise da violên- cia, deve-se pensar no lugar que a intole- rância tem na relação com o outro que se apresenta diferente do padrão conferido e como a ameaça se revela ao acenar a possibilidade de mudanças na órbita do jogo do poder (RIBEIRO, 2008, p. 14).}

Nesses espaços interiores, para a Coroa exercer o pleno governo tornou-se necessário o envio de súditos para esse território. Aí, povos indígenas e colonos tinham diferentes perspectivas com relação à terra. Para o primeiro grupo, como elucida Ribeiro, o território era o espaço da terra onde organizavam a vida da coletividade, já para os invasores\colonizadores, fixarem-se no interior significava antes de tudo a ânsia por riquezas. Assim, pode-se concluir que se tratava da mesma terra, porém vista sob perspectivas distintas. Afinal, além de riqueza, os colonos buscavam a promoção da vida em sociedade e a aquisição de status social.

Após a leitura de algumas fontes, tem-se a impressão que nos sertões a busca pelo ouro e a captura de grupos indígenas eram situações agregadas. Para conseguirem se fixar em lugares remotos era imperativo primeiro conquistar ou aliar-se ao outro. E uma das maneiras para lograr êxito nesse processo era a persuasão dos indígenas, convencendo-os a se incorporarem 
às companhias destinadas a percorrer o interior. Diante dessas ponderações, pode-se afirmar que a melhor saída para os colonos foram os descimentos, embora a violência tenha predominado no contato entre os grupos durante a colonização do interior da capitania. Nas áreas de contato sistemático entre os colonizadores e indígenas, a alternativa dos primeiros para justificarem a escravidão eram as queixas de hostilidade enviadas ao rei de Portugal. Para tanto, foi necessário construir a imagem do indígena como inimigo feroz, indomável e útil apenas quando submetido à escravidão. Mas o rei não estava desatento às intenções dos seus súditos, uma vez que só declarou "guerra justa" quando viu seus interesses adiados pela interferência do gentio. A primeira incursão de Veloso na capitania data de 1705. Naquele ano o dito capitão pede assistência ao Rei para adentrar ao sertão, solicitando a

\section{[...] assistência dos Índios de Vossa Mercê; que para este efeito lhe são precisamente necessários: espero que Vossa Mercê, lhos mande dar todas as vezes que o dito Capitão-mor lhos pedir assim por fazer este serviço a Sua Majestade (BN. Carta que se escreveu ao Coronel Manuel de Araujo de Aragão, e ao Capitão João Rodrigues Adorno, para darem os Índios que lhes pedir o Capitão -mor Antônio Veloso da Silva. (DHBN, v. 41, p. 41 ).}

Para além da questão do mercado de víveres, manter a capitania segura estava relacionado à abertura de caminhos para as Minas do Rio de Contas, região que começava a despertar o interesse da Coroa a partir do século XVIII. Os colonos que seguiam para os sertões sem dúvida nutriam-se da esperança do rápido enriquecimento, fato possível uma vez que a qualquer momento nessas jornadas poderiam ser encontradas mi- nas de ouro e prata. Mas, o que figurou como grande motivador nessas expedições foram as possibilidades de trazer índios dos sertões, medida incentivada inclusive pela legislação indigenista elaborada pela Coroa portuguesa. Logo, para muitos homens a busca de metais preciosos era apenas um pretexto para cativar grupos indígenas, principalmente a partir do contexto sócio econômico em que a capitania estava envolvida.

Após ataques esporádicos na capitania, os índios não contatados eram descritos genericamente pela alcunha de Bárbaros, entre eles estavam ramos dos Gueren, os quais, após um intervalo de calmaria, iniciaram contra-ataques sistemáticos nas vilas do norte da Capitania dos Ilhéus, como nos informa a "Carta que se escreveu ao Sargento-mor da Vila do Cairú Francisco Pinho e Góis, sobre puxar por todos os Capitães-mores das Entradas com seus oficiais, Capitães do mato, e da Ordenança para correrem as cabeceiras e matos das mesmas Vilas".2

Marlinho de Freitas de Couros Carneiro e Lucas da Afonseca Saraiva informa-nos que alguns índios atacaram as suas propriedades, matando um mulato e dois escravos, intimidado tanto aos moradores de Cairú, “que a desamparariam todos, se prontamente se lhe não acudir com o remédio que pede o evidente perigo que os ameaça”. Para livrar a vila, era necessário mandar vinte e cinco ou trinta soldados do Terço ${ }^{3}$ de Henrique Dias, munidos de armas de fogo, pólvora e chumbo, “que é necessário, mas agora convem que Vossa Mercê deite tropas para ao menos afugentar o gentio, enquanto se prepara maior poder para o ir conquistar" (DHBN, v. 43, p. 98).

\footnotetext{
${ }^{2}$ BN. Carta que se escreveu ao Sargento-mor da Vila do Cairú Francisco Pinho e Góis, sobre puxar por todos os Capitães-mores das Entradas com seus oficiais, Capitães do mato, e da Ordenança para correrem as cabeceiras e matos das mesmas Vilas. Documentos Históricos da Biblioteca Nacional, v. 43, p. 98.

${ }^{3}$ Tropa militar composta majoritariamente por negros.
} 
Um mês depois informa-nos Martinho de Freitas sobre o resultado da mesma expedição ${ }^{4}$, descrevendo que havia percorrido os matos e cabeceiras da mesma vila atrás dos índios que haviam matado os escravos, conseguindo afugentá-los, mas esperava que fossem organizados maiores empreendimentos para "maior poder para conquistá-lo nas suas mesmas aldeias. E como a Vossa Mercê toca tanta parte desta diligência, espero concorra para ela, com tudo quanto lhe for possível" (DHBN, v. 43, p. 98).

Nesse mesmo contexto, os índios fizeram algumas mortes no distrito de Mapendipe e uma carta enviada aos oficiais da vila de Cairú pelos moradores da localidade informa-nos que:

Por repetidas cartas, que tive, assim de Vossa Mercê, como de várias pessoas dessa Vila, e de outros lugares circunvizinhos, em que davam conta de haveres descido o Gentio bárbaro, e feito algumas mortes em Marapendipe e haverem os moradores daquelas partes, retirandose para essa Vila (DHBN, v. 43, p. 99).

Diziam os moradores de Mapendipe não entender por que os homens destinados a fazer guerra não haviam passado naquela localidade. Logo abaixo esclarece os moradores que a jornada não foi completada porque a expedição:

[...] padecendo a fomepor Vossas Mercês me haverem segurado assistir com o sustento ordinário, a toda a gente que fosse á mesma empresa. Vossas Mercês me digam a causa, de que procedeu esta dilação: e no caso em que, ainda se ache nessa Vila o Capitão Paulista, com a mais gente que o há de acompanhar, farão Vossas Mercês toda a diligência possível, (DHBN, v. 43, p. 99).

Ocupar os sertões da capitania dos Ilhéus representou, portanto, um grande desafio para Coroa portugue- sa devido à presença de diversos grupos indígenas ainda não atingidos de forma direta pela colonização. Diferentes de outras regiões, a exemplo de Salvador e seu recôncavo, a colonização do interior da capitania permaneceu quase nula ainda nos anos iniciais do século XVIII, quando a Coroa decidiu abrir estradas no interior da capitania para facilitar o acesso às minas do Rio de Contas. Alcançar esses territórios tornou-se uma meta para os homens que buscavam o desenvolvimento econômico, em um movimento que embora tardio ocorreu de forma intensa e se tornou uma das principais ações incentivadas pela Coroa.

Para analisar a expansão das fronteiras da capitania dos Ilhéus e seus principais habitantes, temos que analisar o significado que o sertão pressupunha para os grupos envolvidos. Como nos informa Maria Mader, o conceito de sertão carrega diferentes símbolos e signos que sempre o coloca de modo pejorativo, direcionando -o "a ausência, a ideia de deserto, a falta de governo, de leis, de religião, enfim que representam a ordem e a civilização" (2006, p. 122).

O termo sertão ganha bastante notoriedade nos documento em análise. Ele pode ter uma gama de sentidos entre as quais vale destacar: o sertão enquanto espaço natural de terras férteis e riquezas inexploradas, o sertão enquanto paisagem áspera habitada por feras e homens indômitos. E ainda o sertão como espaço geográfico, cuja designação refere-se a todo lugar de vegetação de caatinga e distante do litoral. Segundo Márcio Santos (2010, p. 350), a escolha da designação do conceito de sertão tratado nos documentos seiscentistas e setecentista depende do autor, do lugar social e da finalidade daquele que escreve.

\footnotetext{
${ }^{4} \mathrm{O}$ tema da expedição ao sertão sempre ocupou um lugar de destaque nos escritos históricos. Na maioria dos casos, os homens que se ocuparam da expansão das fronteiras figuraram como um herói na historiografia tradicional, responsável pelas dimensões continentais do Brasil. Segundo Luiza Volpato, os textos apresentam para o caso de São Paulo "a figura de um sertanista de botas de cano alto, chapéu de aba larga, gibão acolchoado, com uma escopeta ou um bacamarte na mão”. VOLPATO, Luiza. Entradas e Bandeiras. São Paulo: Ed. Global, 1985.
} 
Para além das observações postuladas por Santos, as distintas descrições do sertão, aliás, sertões, inscrevem-se não apenas no sentido geográfico, descrito como áreas distantes do litoral, mas, além disso, o sertão carrega consigo, como descreve Amantino (2008), "representações com sentidos mais sutis, que de uma forma ou de outra acabaram por personificar estas regiões". Assim outra descrição possível para o sertão da capitania era uma região que deveria ser controlada e domesticada. Segundo a autora, a origem da palavra sertão:

[...] é um local inculto, distante de povoações ou de terras cultivadas e longe da costa. É oriundo do radical latino "desertanu" que se traduz como uma ideia geográfica e espacial de deserto, de interior e de vazio. Em fontes de procedencias variadas, o fato do Sertão ser identificado enquanto um deserto, remete sempre à noção de que era vazio de elementos civilizados (AMANTINO, 2008, p. 30).

Diante dessa assertiva de Amantino (2008) e baseando-nos nas fontes, nota-se que as regiões distantes do litoral mostram traços que a ligam a uma suposta ausência de cultura, seja material ou não. Outro elemento significativo tratado nesse fragmento diz respeito ao sertão enquanto um lugar vazio, sem vida. Porém como vimos esse mesmo lugar sem vida abrigavam "criaturas bárbaras", entre eles índios e negros fugidos. A ausência de vida deve ser lida da seguinte forma: não havia nesses lugares vida "civilizada", daí a necessidade desse lugar tornar-se ordenado e controlado, para isso haveria a necessidade de ocupá-lo de forma efetiva por meio de uma "população civilizada".

Esta imagem do sertão se refletiu também em seus habitantes, assim são definidos os grupos indígenas que habitavam a costa $\mathrm{e}$ as feras que infestavam os "distantes sertões", os Tupis e os
Tapuias, nessa ordem. É destas percepções do espaço e dos seus habitantes e das características estrategicamente dadas pelos Tupis a seus contrários, inimigos tradicionais, que são forjadas as categorias de índios que deveriam ser combatidos. Por isso, percebemos nesse trabalho que uma das principais contribuições dos Tupis foi no campo jurídico, localizando os seus inimigos, os quais estavam sujeitos ao extermínio e escravização. Isso explica em parte a adesão de inúmeros índios da costa em guerras para combater seus tradicionais inimigos.

A ocupação rarefeita da Capitania dos Ilhéus e a grande distância entre as vilas manteve as zonas de ocupação sob constantes pressões. A primeira delas diz respeito às constantes ameaças dos grupos indígenas, além disso, vale destacar o perigo eminente de doenças, estiagens e o ataque inesperados de animais selvagens. Como vimos, a ameaça de diferentes grupos indígenas levaram em alguns casos o recuo da ocupação em determinados pontos da capitania. Algumas fontes trabalhadas mostram exatamente esse dado na medida em que os índios não permitiam que se explorasse o interior para além de um limite determinado, tornando grande parte do sul da capitania sem grandes interferências dos colonizadores.

Essa condição não está relacionada apenas à descontinuidade da ocupação. Segundo Márcio Santos (2010, p. 221) no sertão movimentaram-se homens com interesses distintos e muitas vezes suas demandas não convinham aos interesses da Coroa portuguesa. Aliado a esse fator, tem-se a precária presença do Estado português no interior das capitanias, garantindo aos "homens do sertão" uma condição de autonomia que não desfrutavam nas regiões litorâneas. Entender as diferentes perspectivas dos grupos envolvidos na colonização das fronteiras mostra-se de suma valia para a 
compreensão do processo de ocupação do interior da Capitania dos Ilhéus.

O olhar dispensado pelas fontes oficiais é o da expansão da civilização sobre a barbárie indígena. Assim, os distintos grupos foram estereotipados e condensados sob a alcunha de bárbaros, categoria jurídica que não contribui para compreender as sociedades indígenas no período de conquista do interior. Nas fontes consultadas é comum o uso das categorias bárbaro, Gueren, Aimoré e Tapuias como sinônimos dos diversos grupos indígenas que ocupavam o interior da capitania. Todos esses termos denotam a impossibilidade de se reconstruir as identidades étnicas no contexto colonial, originados de fontes preocupadas apenas com os interesses materiais do colonizador, entre esses estavam os grupos sujeitos ao cativeiro.

Relacionadas à dificuldade de se identificar os povos estavam as características culturais de alguns grupos, entre os quais figuravam os Gueren, uma vez que esses estavam sujeitos ao fracionamento, fazendo com que um mesmo grupo ganhasse diversas denominações. Desfazer essa homogeneização, estabelecendo o modo de vida de cada grupo étnico seria uma das mais valiosas contribuições de uma pesquisa nessa área, porém o caráter pouco elucidativo das fontes tem limitado esse trabalho por parte dos historiadores.

Anos após os ataques a Mapendipe, foi a vez das vilas de Camamú e Jequiriça, sofrerem com as incursões, causando nesta última o assassinato de "três negros e fez outros insultos que para os evitar tenho resoluto mandar-lhes fazer guerra para que por este meio se lhe dê o castigo que merecesse" (DHBN, v. 69, p. 213). Muitos desses contra-ataques originavam-se dos ataques iniciais dos colonos, os quais usavam como estratégias o aprisionamento de mulheres e crianças como forma de atrair os homens, mais úteis para as lavouras e para integrar as tropas de guerra. É esse fato que uma fonte nos deixa transparecer ao aconselhar o Capitão-mor Francisco Marques de Oliveira retornar logo ao seu arraial, pois “[...] devemos recear muito que em satisfação e vingança de o desinquietarmos pròximamente da sua aldeia e das cinco crianças que se lhe apanharam repita as suas costumadas hostilidades ou nos distritos do Cairu ou nas estradas das Minas”(DHBN, v. 75, p. 91).

Após sua primeira decida ao sertão, percorrendo o norte da capitania, desde a Vila de Cairú até o extremo sul da vila de Barra do Rio de Contas, o Capitão-mor Antônio Veloso da Silva deveria ir com sua Companhia as

[...] partes por donde e como se há de fazer a dita entrada a qual fará na forma que assentarem mandando primeiro lançar o bando incluso, o qual fará executar inviolavelmente, e no mais seguirá o regimento que leva de sorte que acrescente mais este serviço aos que tem feito a sua Majestade para que com a sua real atenção atenda aos requerimentos que lhe fizer (DHBN, v. 69 , p. 213).

Para executar as ações com mais eficiência, Veloso da Silva foi nomeado Cabo de Guerra, levando consigo um Regimento passado por Dom Sancho de Faro e Souza, conde do Vimeiros, a 25 de Agosto 1719. Essa grande jornada sairia do distrito de Maragogipe, com cinquenta homens armados e alguns índios que seriam conduzidos por um dos integrantes da armada, o Coronel Manuel de Araújo de Aragão. Da Vila de Jaguaripe também sairiam soldados brancos e índios armados das aldeias daqueles distritos, comandados pelo Sargento-mor Manuel Pinto de Eça, ficando um tempo arquartelados na vila do Cairú, esperando melhores condições para seguir “porque vão, não só em serviço de Sua Majestade, mas também o seu, e de seus vizinhos". Nessa última vila ordenava o conde do Vimeiros que: 
Com todo o dito corpo de gente unido, pacifico, e bem tratado assim brancos como índios, tendo este especial cuidado e vigilância, para que não fujam, fará transito o dito Cabo para a Vila de Cairú, e aos oficiais da Câmara dela ordenei, tenham prontos os mantimentos como prometeram, (DHBN, v. 55, p. 308).

A Vila de Camamu disponibilizaria cinquenta homens armados e também o número de sírios de farinha, carnes, e peixes secos "em que pudessem [seus moradores] acudir". Uma empresa como essa que visava conquistar uma extensa área do interior da Capitania dos Ilhéus, necessitava além de armamentos, o estabelecimento de roças, as quais garantiriam o fornecimento de víveres para a permanência da tropa por longos períodos no interior. Essas roças na maioria das vezes eram plantadas nos arraiais, as quais além de fornecerem suprimento de víveres, tinham a função propriamente militar. Em alguns casos, como esclarece Márcio Santos, os arraiais de maior relevância se tornaram posteriormente as principais vilas do sertão $(2010$, p. 103).

Em outros documentos relativos à guerra, encontramos menção ao uso de utensílios como fumo, pentes, tesouras e miçangas. Esses itens serviam, antes para "meter de paz" os não contatados assim como para a "felicidade dos que vão". A partir desta informação, podemos afirmar o quanto importante para os colonos eram as alianças com os índios, mas de maneira nenhuma podemos interpretar as alianças como uma forma de traição ou rendição dos índios, uma vez que mesmo os grupos aliados reagiam violentamente sempre e quando suas demandas não eram cumpridas.
Os indígenas aliados também figuravam como possibilidade de povoamento das áreas pouco ocupadas, além disso, eram as bases militares responsáveis pela manutenção dos novos territórios, servindo de barreiras contra os inimigos internos e outras nações europeias. Assim, como observa Puntoni (2002, p. 51), tratava-se de garantir os índios aliados como base populacional, embora para a Coroa fosse mais atraente a vinda de colonos europeus com cabedais, capazes de realizar o enriquecimento da colônia.

A quantidade e a intensidade de índios nessas jornadas ${ }^{5}$ mostra a dependência que os colonos tinham desses grupos. Se confiarmos o que nos sugerem as fontes, um possível abandono indígena ${ }^{6}$ nessas expedições significaria o fracasso total dessas jornadas, uma vez que os conhecimentos dos caminhos, a habilidade com as armas e os conhecimentos alimentares de determinadas plantas e frutos garantiram não só o sucesso das entradas, mas também a sobrevivência de seus participantes.

O sexto capítulo do Regimento passado a Veloso da Silva dizia respeito aos possíveis comportamentos dos homens nessas jornadas, pois a qualquer momento "algum soldado branco ou índios, seja rebelde, e desobediente,deserte, ou possa cometer outro crime,". Para evitar essas desordens, o sobredito Veloso os remeteria logo presos com toda a segurança, dando conta ao Conde de Vimeiros "suas culpas com toda a miudeza para eu mandar executar nele, o castigo que por ela merece". E ainda ratificava:

\footnotetext{
${ }^{5}$ Como observamos no primeiro item desse capítulo, desde o Regimento de Tomé de Souza está presente a determinação de se expandir a colonização para além da linha litorânea. Rege o regimento que Tomé de Souza tinha a obrigação de zelar pela segurança da colônia e do povoamento das novas terras, contando com a armada, gente, artilharia, armas e munições e tudo o mais que fosse necessário. Aponta Puntoni que na América portuguesa desde os anos iniciais organizaram-se os órgãos responsáveis pela manutenção e garantia do poder da Coroa portuguesa em territórios de além-mar, concorrendo para isso as forças militares, as quais também se envolviam na repressão de grupos indígenas que não estavam colaborando com a expansão. Mas, ao tempo do primeiro governador, a administração pública contava com braços armados, o suficiente para livrar a colônia de inimigos internos e externos, contando para isso com obtidos junto a grupos tribos aliado, assim como os "soldados das linhas auxiliares". PUNTONI, 2002, p. 189.

${ }^{6}$ A presença do indígena era constante nessas jornadas e acabaram se tornando atividade obrigatória conforme o Regimento das Missões. Os índios foram organizados, conforme Puntoni, em companhias chefiadas pelo capitão de aldeia ou capitão da nação. Na maioria dos casos, esse posto era ocupado pelos principais das tribos aliadas.
} 
[...] todos os oficiais, Soldados brancos, e indios que vão em companhia do dito cabo, para a guerra dos referidos bárbaros, obedeçam prontamente com deve, e são obrigados, em tudo o que toca á mesma guerra, para que por demora, omissão, ou falta, se não deixem de conseguir (DHBN, v. 55, p. 308).

A conquista de novos espaços, a busca por metais preciosos e as recompensas pela participação nas guerras de combate aos índios foram as principais motivações que nortearam os colonos a se integrarem nas tropas de guerras justa. Comumente utilizado, o termo conquista aparece com frequência na documentação para designar todas as jornadas ao interior. Conquista, como nos informa Márcio Santos (2010, p. 59.) possui uma gama de significados e esta relacionada tanto ao confronto entre grupos indígenas e colonos quanto à ocupação efetiva do território. Para o primeiro caso, como pondera Santos, o termo também pode se referir apenas a situações de guerra decretada aos índios, sem sua escravização propriamente dita. A terceira aplicação de termo diz respeito ao deslocamento de índios para o interior de um agrupamento jesuítico, denominado de aldeamento. Neste sentido temos a Conquista Espiritual.

Para o caso da capitania dos Ilhéus, que era composta basicamente por colonos de condições modestas, a opção desses homens por se integrarem as tropas dos Capitães tornou-se um dos principais meios para ocupar um lugar de destaque na hierárquica sociedade colonial, já que a limitada condição econômica os excluía. Para esses indivíduos, encontrar uma jazida mineral passou a ser um sonho e uma possibilidade, na medida em que foi encontrado ouro no sertão do Rio de Contas. Por isso, inúmeros homens saíram em jornadas tanto da capitania dos Ilhéus como de outras áreas para explorar o seu interior. Mas, para evitar as grandes ambições provocadas "pelas lonjuras dos certões", todas as manhãs os "homens e índios", “[...] Tanto que tiver guarnecidos de munições de boca e guerra na Vila do Cairú, e assentado o dia em que há de entrar as matas, e principiar as marchas, fará na véspera confessar, e comungar toda a dita gente de guerra" (DHBN, v. 55, p. 308).

Nota-se de início que, além de homens e armas, a presença dos missionários era de suma importância, trazendo aos partícipes palavras de conforto nos momentos difíceis. Além disso, os missionários aproveitavam essas "empresas" para catequizar e batizar os índios, "livrando-os da prática dos seus ritos", levando grande parte dos convertidos para trabalhar nos aldeamentos. Ainda nesse contexto, foi expedido um documento em Portugal para reforçar e regulamentar a fixação dos índios nos aldeamento, onde o Rei determina que a cada missão se dê uma légua de terra em quadra para sustentação dos índios e missionários, essa medida tinha como principal objetivo fazer povoar o interior, incentivando os religiosos a acompanharem tais expedições, criando aldeamento que serviriam de base para as expedições, dadas as distâncias entre as vilas da Capitania. Na ocasião da jornada aqui tratada, o missionário deveria ajudar:

[...] O dito Cabo Antônio Veloso da Silva tanto, que avista os bárbaros lhe não fará logo resolutamente guerra, mas sim lhes antecipará embaixada, para que se sujeitem, e tribute a obediencia de Sua Majestade, o que fará a tal tempo e horar, que se não perca por ser tarde a ocasião da guerra que se lhes houver de fazer ; e cedendo os ditos bárbaros á paz, os tratará logo o dito Cabo com todas as demonstração dela como serventes e leais de Sua Majestade (DHBN, v. 55, p. 308).

Casos os índios se mostrassem resistentes, Antônio Veloso poderia logo declarar-lhes Guerra Justa,

[...] tão veemente e rigorosa que ou os destrua todos como inimigos declarados, ou os prisione; o que assim eveitará o 
dito Cabo em todos os bárbaros que tiver noticia, que residem ou andam dispersos e pombeando nos distritos das sobreditas vilas até totalmente ficarem extinguidos de tais bárbaros, e os que se prisionarem na dita guerra ficarão captivos da Provisão de Sua Majestade e lei de 611 (DHBN, v. 55, p. 308).

Contrapondo-se as determinações da legislação do período, esta expedição usava como base para o cativeiro indígena a extinta lei de 1611 , atendendo aos anseios dos colonos. Nessa legislação, a liberdade dos índios é reconhecida em tese, mas os que não estivessem colaborando com a colonização estavam sujeitos a escravidão. Dizia ainda aquela lei que era considerado legítimo o cativeiro não só dos aprisionados em guerra justa, mas também dos resgatados, que serviriam como cativos por 10 anos, "quando comprados por preço não excedente ao taxado pela Junta, e perpetuamente se fosse superior" (MALHEIROS, 1944, p. 65). No que se relacionavam as guerras, estas só seriam justas em casos de levantes ou rebelião:

[...] que se fizesse com sua licença ou do Governador das ditas partes, e os que salteassem os Portuguezes e outros Gentios para os comerem, com declaração, que as pessoas, que pela dita maneira os captivassem, dentro de dousmezes primeiro seguintes, (REVISTA TRIMESTRAL DE HISTÓRIA E GEOGRAPHIA... p. 7-8, 1973).

Porém, no contexto da guerra, essa lei tornou-se ilegal, pois esta jornada ocorreu no século XVIII, cem anos após sua revogação. No momento da expedição estava em voga o Regimento das Missões, o qual não estabelecia o cativeiro com tanta liberdade como a lei de 1611. Para o Regimento de 1688 no seu capítulo vigésimo se estabelecia que:

[...] todas as vezes que os moradores houverem de ir ao sertão, arbitrando-se primeiro o número de indios, que necessitam para lhe remarem as canoas se lhe dará a metade deles somente das aldeias da repartição, e a outra a metade procu- rarão os tais moradores trazer das outras aldeias, que costumavam servir pela convenção que com eles faziam, por quanto com a taxa dos salários fica remediado o dano, que sentiam no excesso deles, e os Padres Missionários das ditas aldeias terão cuidado de que os ditos indios se não escusem sem justa causa pela conveniência que terão do seu trabalho, e pelo que a todos resulta do comércio dos sertões, e não será razão bastante para não entrarem na dita repartição nos moradores, que tiverem escravos próprios porque além de serem necessários para as suas fábrica, não é justa que se exponham a lhe fugirem para os sertões, como tem sucedido muitas vezes $(\mathrm{ABN}$. v. 66, Rio de janeiro: Imprensa Nacional, 1948, p. 57-59).

A partir da efetivação da lei de 1686, chamada Regimento das Missões, os jesuítas voltam a ter o controle dos aldeamentos, mas, a partir desse contexto, os colonos possuíam o livre acesso aos trabalhadores indígenas, mediante o pagamento de um salário. Essa lei também regulamentou, que aos indígenas, cabia a defesa da colônia, estabelecendo, além disso, sua total liberdade, mesmo quando fossem casados com escravos negros. Nada mais conveniente aos colonos que preferir as resoluções de 1611. Diante desse exemplo, pode-se afirmar que a legislação não foi a grande reguladora das relações entre os grupos índios e os colonos. A dinâmica da sociedade era ditada pelos próprios sujeitos coloniais, os quais ditavam, junto ao governo metropolitano e, principalmente as Câmaras locais, o ordenamento social. No que diz respeito à legislação indigenista, por tratar diretamente de assuntos de grande valia para os colonos e jesuítas assumiu um caráter oscilante dentro da realidade colonial. Dentro do emaranhado legislativo, houve leis de maior abrangência, a exemplo do Regulamento das Missões de 1680, e outras de caráter específico e até localizadas espacialmente, fazendo como analisa Paraíso "que a articulação entre as várias leis só possa ser percebida ao se destacar o alcance e o objetivo de cada uma delas" (PARAÍSO, 1998, p. 23). 
As expedições que rumaram ao sertão quase nunca desperdiçavam seu tempo, uma vez que se não conseguissem seu objetivo maior, o ouro, poderiam fazer resgates, os quais era um dos mecanismos legítimos para conseguir mão de obra escrava. Vigorava a lei que as tropas poderiam adentrar o sertão em busca de índios que estivessem "presos à corda", mantendo-os cativos durante cinco anos, os chamados escravos de condição. Diante dessa afirmação, nota-se a variedade de funções que uma tropa desempenhava.

Essas jornadas eram compostas por diversos atores sociais, desde soldados portugueses e mestiços a índios e negros, os quais criaram uma rede de sociabilidade não só com a tropa, assim como com os grupos étnicos descidos ou apreendidos como escravos. Conforme Rafael Chambouleyron, Bonifácio e Melo (2005), a duração dessas jornadas é um indicativo da integração estabelecida entre esses atores, uma vez que, em alguns casos, as expedições duravam anos.

Os investimentos destinados para essas expedições eram muito grandes. Vários homens saiam da capitania para o sertão, necessitando de víveres, munições, roupas e remédios. Algumas expedições permaneciam por vários meses e até anos distantes dos núcleos litorâneos, dependendo de sua capacidade bélica e dos mantimentos levados do litoral para lograr o êxito necessário. Caso conseguissem cumprir seus objetivos, eram divididos os lucros entre os participantes, como informava o capítulo onze do Regimento:

O dito Cabo de todos os bárbaros, que prisionar na guerra homens, e mulheres, grandes e pequenos, fará logo inventário, que assinará e os mais Capitães, e oficiais, que leva em sua campanha, e de toda a somará o quinto é devido a Sua Majestade, e o remeterá seguro a esta Praça para se pôr em arrecadação pela sua Real Fazenda para suprimeto das despesas que fez na dita guerra.Também ficará a joia que pertence a este Governo Geral e a remeterá a esta cidade, separada dos quintos, de Sua
Majestade.Tiradas estas duas partes superiores, todos os mais bárbaros que ficarem prisioneiros os fará o dito Cabo pôr em praça na Vila do Cairú, a quem por eles mais der, (DHBN, v. 55, p. 308).

É digno de nota que as jornadas que saíram de Ilhéus tinham a Coroa portuguesa como a sua principal armadora, por isso ocorria sua intensa participação no espólio de guerra. Essa foi uma das principais diferenças entre as expedições que saíram da Capitania dos Ilhéus e as que atuaram na capitania de São Vicente, denominada pela historiografia de bandeiras. Para o caso do planalto paulista, os homens percorriam o sertão com o principal objetivo de buscar mão de obra indígena escrava, uma vez que os preços altos dos escravos africanos limitavam o acesso dos moradores do planalto (VOLPATO, 1986, p. 45). Já para o caso de Ilhéus, o que mais influenciou sua atuação foi inicialmente a defesa das áreas produtoras de mantimentos. Porém apesar das diferenças apontadas quanto a seu caráter, ambas desenvolveram-se atividades condizentes aos interesses metropolitanos.

Assim como o caso do planalto paulista, as jornadas que saíram de Ilhéus não tinham apenas índios como alvo, pois, como dizia o regimento, haviam alguns "mocambos de negros fugitivos" na região que deveriam ser extintos, para isso o Capitão Veloso da Silva deveria encontrar os

[...] sítio de mocambo de negros que andam fugindo a seus senhores e dará assalto nos ditos mocambos, e trará consigo todos os negros, e negras a crias que se achar para se entregar a seus donos que são obrigados a dar por cada um deles (DHBN, v. 55, p. 308).

Esse mocambo tinha o nome de Camisão e era o local onde se concentrava a maioria dos escravos fugitivos das Vilas de Baixo. No Regimento de 1719 ficavam claras as determinações dos envolvidos na 
jornada, qual seja, receber uma quantia por cada negro fugitivos. Mas ora ou outra alguns donos não cumpriam o Regimento, a exemplo de Almeida Sandi e Salvador Machado, os quais escreveram uma carta ao Capitão Antônio Veloso da Silva se recusando a pagar a quantia por cada negro foragido, uma vez que "os negros que prisionou, nenhum era criminoso, e os que o eram, fugiram uns, e dois morreram na resistência que fizeram".

\section{Considerações Finais}

Nas linhas antecedentes, presenciamos uma grande heterogeneidade dos povos que habitavam o sertão. Esse espaço era perspectivado pelas autoridades competentes como um mundo diverso do observado no litoral. Como nos pondera Pedro Puntoni, os indígenas que viviam nestas localidades eram descritos pelo termo TapuialBárbaro, e para o nosso caso, Aimoré\Gueren. Por outro lado, o Tapuia também poderia ser destinado aos aldeamentos, desde que aceitassem os descimentos propostos pelos padres. Finalmente, para que mais nos interessa, outro elemento definidor do termo Tapuia era a situação geográfica em que viviam. Desse modo, esses povos eram confundidos com a áspera vegetação dos sertões, traduzindo-se em comportamentos e atitudes bestiais, quando não objeto de manipulação do demônio, como queriam alguns religiosos.

Como observado, nos anos iniciais da colonização, o termo Tapuia atendia a uma alteridade entre os povos que viviam no litoral e no interior, vale destacar que este termo era utilizado pelos Tupis para designar os seus contrários. Mas, posteriormente, esse termo incorporou-se ao sistema jurídico português, passando a ser traduzido em povos que estavam sujeitos ao cativeiro. Por essa perspectiva que está em tela, Tapuia e, em alguns momentos AimorélGueren, não significava um etnônimo, mas um termo que se incorporou aos dicio- nários jurídicos e que por trás dessa categoria estavam os interesses dos diversos sujeitos da colonização.

É preciso deixar esclarecido que os Bárbaros, descritos pelos documentos, não lutavam de forma unificada com o objetivo de expulsar Portugal da Colônias, como querem os documentos. Ao que parece, a noção de confederação dos índios também se torna problemática, os Gueren tinham uma forte tendência ao processo de cisão, dificilmente podendo se constituir enquanto um exército unificado. Como afirmamos, o desejo de fazer-se senhores de outros homens, fez com que os índios AimorélGueren fossem caracterizados como aquele que deveria ser extinto, daí as descrições emanadas dos documentos, os colocando na categoria de inferiores e violentos.

Ao se tornarem aliados, os Gueren desfrutaram de todas as prerrogativas que essa categoria lhes proporcionavam. Mas embora possamos fazer ponderações no sentido de mostrar os índios enquanto seres criativos, incorporando-se ao sistema colonial quando havia possibilidade - inclusive reinventando suas formas de agir frente ao mundo colonial -, não podemos cair nas armadilhas de alguns autores contemporâneos que deixam de denunciar o caráter violento das relações vividas pelos indígenas no ambiente colonial. Reconhecer que os impactos sofridos pelos grupos indígenas não significa enquadrálos na categoria de sujeitos pacientes e vítimas da história, mas assume um tom de denúncia frente às atrocidades sofridas. Podemos afirmar, com base na documentação, que as relações entre os grupos em espaços com o caráter dos aldeamentos, sustentados pelo discurso humanista, na maioria das vezes assumiam o caráter de dominação, impondo-se rígidas relações de hierarquização, ocupando os dominados uma posição social inferior aos demais membros da comunidade com os quais conviviam. 


\section{Referências bibliográficas}

AMANTINO, Márcia O Mundo das Feras: Os Moradores do Sertão Oeste de Minas Gerais - século XVIII. São Paulo: Annablume, 2008.

AMOROSO, Marta. Mudança de Hábito: catequese e educação para índios nos aldeamentos capuchinhos. Revista Brasileira de Ciências Sociais, São Paulo, v.13, n. 37, 1998.

CHAMBOULEYRON, Rafael; MELO Vanice Siqueira de; BOMBARDIO, Fernanda Aires. Estrondo das Armas: Violência, guerra e trabalho indígena na Amazônia (séculos XVII e XVIII) Projeto História, São Paulo, n. 39, p. 115-137, jul/dez. 2009.

CHAMBOUlEYRON, Rafael; BONIFÁCIO, Monique S.; MELO, Vanice S. de; Pelos sertões "estão todas as utilidades". Trocas e conflitos no sertão amazônico (século XVII). Revista de História 162 (1 semestre de 2010), p. 13-49, 2010.

MADER, Maria Elis Noronha de Sá. Civilização e Barbárie: a representação da nação nos textos de Samiento e do Visconde de Uruguai. 2006. f. 262. Tese (Doutorado), Programa de Pós-Graduação em História, Universidade Federal Fluminense, Niterói, 2006.

MALHEIROS, Márcia. Homens da fronteira. Índios e capuchinhos na ocupação dos sertões do Leste, do Paraíba ou Goytacazes. Séculos XVIII-XIX. 2008. f. 401. Tese (Doutorado em História), Programa de Pós-Graduação em História, Universidade Federal Fluminense, Niterói, 2008.

PARAÍSO, Maria Hilda Baqueiro. O tempo da dor e do trabalho. A conquista dos territórios indígenas nos sertões do leste. 1998. v. 5. Tese (Doutorado em História Social), Faculdade de Filosofia, Letras e Ciências Humanas, Universidade de São Paulo, São Paulo, 1998.

PUNTONI, Pedro Luis. A arte da guerra no Brasil. Tecnologia e estratégia militar na expansão da fronteirada América portuguesa, 1550-1700, p. 188.

. A guerra dos bárbaros: povos indígenas e colonização do sertão nordeste do Brasil, 1650-1720. São Paulo: Hucitec/Edusp/Fapesp, 2002.

RIBEIRO, Núbia Braga. Os Povos indígenas e os Sertões das Minas do Ouro no século XVIII. Departamento de História, FFLCH, USP-SP, 2008.

SANTOS, Márcio Roberto Alves. Fronteiras do sertão baiano: 1640-1750. 2010. f. 433. Tese (Doutorado), Programa de Pós-Graduação em História Social, Universidade de São Paulo, São Paulo, 2010.

VOLPATO, Luiza. Entradas e Bandeiras. São Paulo: Ed. Global, 1985.

\section{Fontes Históricas}

BN, Carta para o Governador da Capitania dos Ilhéus Antônio de Couros Carneiros sobre a jornada do Sertão. Documentos Históricos da Biblioteca Nacional, v. 41, p. 41

BN. Carta que se escreveu aos oficiais da Câmara da Vila de Cairú. Documentos Históricos da Biblioteca Nacional, v. 43, p. 99.

BN. Nomeação de Cabo para a guerra dos bárbaros do Cairú e Jequiriça, feita nos Tenente General da Artilharia Francisco Lopes Vilas Boas. Documentos Históricos da Biblioteca, Nacional, v. 69, p. 213. 
BN. Portaria para o Capitão-mor Francisco Marques de Oliveira. Documentos Históricos da Biblioteca Nacional, v. 75, p. 91.

BN. Nomeação de Cabo para a guerra dos bárbaros do Cairú e Jequiriça, feita nos Tenente General da Artilharia Francisco Lopes Vilas Boas. Documentos Históricos da Biblioteca Nacional, v. 69, p. 213.

Regimento que o Capitão-mor Antônio Veloso da Silva, Cabo de toda a gente bárbara e índio levou, para observer enquanto durar a guerra, que é mandado a fazer ao gentio bárbaro, dos matos do termo da Vila do Cairú e das cincunvizinha a ela. Documentos Históricos da Biblioteca Nacional, v. 55, p. 308.

ABN. Anais da Biblioteca Nacional do Rio de Janeiro- Livros Grosso do Maranhão, v. 66, Rio de janeiro: Imprensa Nacional, 1948, p. 57-59.

Submissão: 08/03/2016

Aceite: $20 / 06 / 2016$ 